\title{
Female crack cocaine users under treatment at therapeutic communities in southern Brazil: characteristics, pattern of consumption, and psychiatric comorbidities
}

\author{
Mulheres usuárias de crack-cocaína em tratamento em comunidades \\ terapêuticas no sul do Brasil: características, padrão de consumo e \\ comorbidades psiquiátricas
}

Adriana Raquel Binsfeld Hess, ${ }^{1,2}$ (D) Rosa Maria Martins de Almeida ${ }^{1,2}$ (D)

\begin{abstract}
Objective: To explore and describe sociodemographic characteristics, crack consumption patterns, and psychiatric comorbidities of female crack users receiving treatment at therapeutic communities.

Methods: This was a cross-sectional, descriptive, quantitative study. Forty-six women who abstained from crack use were assessed using a sociodemographic questionnaire, the MiniMental State Examination (MMSE), the Structured Clinical Interview for DSM-IV Axis I Disorders (SCID-I), and a profile of crack use questionnaire. Descriptive statistical analyses were conducted.

Results: Participants had a mean age of 31.02 years (standard deviation $[S D]=7.73)$, most were single $(76.1 \%)$, white $(67.4 \%)$ and had complete or incomplete elementary education (43.5\%). Before treatment, $65.2 \%$ of the women reported using crack every day; $46.3 \%$ smoked between 10 to 30 crack rocks per week. Mean treatment time was 63.56 days $(S D=75.85)$, with a mean of 80.41 days of abstinence $(S D=74.52)$ and 3.37 previous treatments $(S D=5.49)$. Mean age upon crack use initiation was 22.61 years $(S D=8.06)$, and the most frequent motivation to start using crack was curiosity $(78.3 \%)$. The mean lifetime duration of crack use was 82.26 months (SD $=74.76)$, and the physical complications most frequently reported were weight loss $(93.5 \%)$, followed by sleep problems ( $87 \%)$. In this study, the most prevalent psychiatric diagnoses were major depressive episode $(60.87 \%)$, followed by post-traumatic stress disorder $(52.17 \%)$ and generalized anxiety disorder (13.07\%). Conclusions: Overall, a pattern of high consumption of crack was observed. The results show a high frequency of mood and anxiety disorders, with the highest frequencies found for major depressive episode and post-traumatic stress disorder.
\end{abstract}

Keywords: Crack cocaine, comorbidity, public health, therapeutic community, women.

\section{Resumo}

Objetivo: Explorar e descrever características sociodemográficas, padrão de consumo e comorbidades psiquiátricas em mulheres usuárias de crack recebendo tratamento em comunidades terapêuticas.

Método: Estudo transversal, descritivo e quantitativo. Quarenta e seis mulheres abstinentes de crack responderam a um questionário sociodemográfico, ao Mini-Exame do Estado Mental (MEEM), à Entrevista Estruturada do DSM-IV para Transtornos do Eixo I (SCID-I) e a um questionário sobre padrão de consumo de crack. Foram realizadas análises estatísticas descritivas dos dados.

Resultados: As participantes tinham média de 31,02 anos [desvio padrão $(\mathrm{DP})=7,73]$, eram na maioria solteiras $(76,1 \%)$, brancas $(67,4 \%)$ e tinham ensino fundamental completo ou incompleto $(43,5 \%)$. Antes do tratamento, $65,2 \%$ das mulheres relataram usar crack todos os dias; $46,3 \%$ fumavam entre 10 e 30 pedras de crack por semana. O tempo médio de tratamento foi de 63,56 dias ( $D P=75,85)$, com média de 80,41 dias em abstinência (DP $=74,52)$ e $3,37(D P=5,49)$ tratamentos anteriores. A idade média de início do uso de crack foi de 22,61 anos ( $D P=8,06$ ), e a motivação mais frequente para iniciar o uso de crack foi a curiosidade (78,3\%). A duração média de uso de crack na vida foi de 82,26 meses ( $D P=74,76$ ), e as complicações físicas mais frequentemente relatadas foram perda de peso $(93,5 \%)$, seguida por problemas de sono $(87 \%)$. Neste estudo, os diagnósticos mais prevalentes foram episódio depressivo maior $(60,87 \%)$, seguido por transtorno de estresse pós-traumático $(52,17 \%)$ e transtorno de ansiedade generalizada (13,07\%).

Conclusões: Em geral, observamos um padrão de alto consumo de crack. Os resultados mostram alta frequência de transtornos de humor e ansiedade, com maiores frequências para episódio depressivo maior e transtorno de estresse pós-traumático.

Descritores: Cocaína crack, comorbidade, saúde pública, comunidade terapêutica, mulheres.

\footnotetext{
${ }_{1}$ Programa de Pós-Graduação em Psicologia, Instituto de Psicologia, Universidade Federal do Rio Grande do Sul (UFGRS), Porto Alegre, RS, Brazil. ${ }^{2}$ Laboratório de Psicologia Experimental, Neurociências e Comportamento (LPNeC), UFGRS, Porto Alegre, RS, Brazil.

Submitted Nov 14 2018, accepted for publication Mar 242019.

Suggested citation: Hess ARB, de Almeida RMM. Female crack cocaine users under treatment at therapeutic communities in southern Brazil: characteristics, pattern of consumption, and psychiatric comorbidities. Trends Psychiatry Psychother. 2019;41(4):369-374. http://dx.doi.org/10.1590/2237-6089-2018-0089
} 


\section{Introduction}

The use of crack cocaine (crack), a form of cocaine that is smoked, is an outspread phenomenon that mobilizes societies, public authorities, and public health services. Worldwide, it is estimated that around 18.2 million people make use of cocaine, with a noticeable increase of almost $7 \% .{ }^{1}$ The Americas are the biggest market, and Brazil is assumed to be the second greatest consumer market for cocaine worldwide, second only to the United States. ${ }^{2}$ According to the Brazilian National Institute of Public Policies on Alcohol and Other Drugs (Instituto Nacional de Ciência e Tecnologia para Políticas do Álcool e Outras Drogas [INPAD]), in 2012, 2.6 million Brazilians had used some form of cocaine (powder cocaine, crack cocaine, merla, or oxi). It was also estimated that 1 in every 100 adults smoked crack in that same year, at a total of 1 million Brazilians. ${ }^{3}$ These epidemiological estimates lay out the burden of cocaine and crack consumption on users, their families, Brazilian society, and public health services.

Crack is a powerful stimulant, which activates the brain's reward system and causes deleterious consequences to all areas of the user's life. 4,5 People who use crack are frequently exposed to a variety of risk factors associated with low quality of life and potentially life threating situations. 6,7 Therefore, crack use leads to a marginalized life that increases the number of clinical conditions, including psychiatric comorbidities. ${ }^{8}$

Studies have sought to identify the characteristics of this population to propose effective treatment and prevention programs. ${ }^{9,10}$ However, while the consumption of crack has increased in the female population, the bulk of those studies focus on male users. Thus, there is still much to learn about the specificities of female crack users. Researchers have identified differences between men and women regarding their drug use patterns, the consequences to their health and psychosocial life. ${ }^{11}$ Some studies showed that women experience a rapid progression from the beginning of drug use to the onset of drug-related problems as compared to men. ${ }^{12}$

Regarding treatment for substance use disorders, the demand for crack use treatment is increasing, ${ }^{13}$ and women have been seeking more help at public facilities. A 14-year cross-sectional study with Brazilian women evidenced that the rate of women looking for treatment because of crack use increased from $2.8 \%$ in 1997 to $67.8 \%$ in 2010, indicating a significant increase in the consumption of crack among women. ${ }^{14}$ It is also important to consider evidence suggesting that women must overcome many barriers to enter treatment, and therefore have less opportunities for treatment associated with drug use. ${ }^{15}$ Those barriers are mainly associated with social stigma, concerns about childcare, lack of awareness of the range of treatment options, economic factors, and the time needed to get treatment. ${ }^{16}$

The pattern of crack use, regarding frequency and quantity, is associated with the severity of health and social consequences, such as HIV risk behaviors, violence, legal problems, and unemployment.10,17,18 Another important aspect is the use of crack use concurrent with other psychiatric problems and other drugs. ${ }^{19-21}$ The symptoms of certain psychiatric disorders can act as risk factors for addictive behavior and may result in negative outcomes, jeopardizing treatment maintenance. ${ }^{22,23}$

Despite the increase in drug use, little information is available on female crack cocaine users in Brazil. Moreover, Brazilian studies are mostly focused on white male and female populations. ${ }^{17-20}$ Therefore, the purpose of this study was to describe sociodemographic characteristics, crack consumption patterns, and psychiatric comorbidities present in female crack users receiving treatment at therapeutic communities in the metropolitan area of Porto Alegre, southern Brazil.

\section{Methods}

\section{Sample and design}

This was a cross-sectional, descriptive study. It is part of a larger study that investigates crack use among women. The selected sample consisted of 46 female users of crack, admitted to four therapeutic communities in the metropolitan area of Porto Alegre, state of Rio Grande do Sul, southern Brazil, following in-hospital detoxification (previous inhospital detoxification is mandatory for all therapeutic communities). Inclusion criteria were being 18 to 50 years old, having been diagnosed with substance abuse disorder as assessed by the Structured Clinical Interview for DSM Axis I Disorders (SCID-I), having crack as the drug of choice, having been abstinent for at least 20 days, and scoring $\geq 18$ on the Mini-Mental State Examination (MMSE). Exclusion criterion were being illiterate, showing symptoms compatible with or having been diagnosed with mental deficiency, schizophrenia, dementia, or psychoses. The exclusion criteria were verified on the patients' medical records, provided by the therapeutic community. However, it is important to note that no participant was excluded from the study due to the exclusion criteria. The use of prescribed psychopharmacological drugs (e.g., antidepressants, antipsychotics) was not considered as an exclusion criterion, as their use was expected in the context 
of treatment for substance abuse. Participants who reported concurrent use of other drugs were included as long as crack was the main drug of use and the main reason for their current treatment.

\section{Instruments}

Sociodemographic questionnaire

This instrument was developed by the research team for the specific purpose of this study, to obtain information on age, education, marital status, profession, socioeconomic status, initiation of drug use, and days of treatment.

\section{Mini-Mental State Examination (MMSE) ${ }^{24}$}

This screening instrument provides information on cognitive parameters. Items are divided into seven categories, each one designed to assess specific aspects: temporal orientation, spatial orientation, attention and calculation, recollection, language, and motor skills. It took approximately 10 minutes for the examiner to apply the test. Scores ranged from 0 to 30 points. Women who scored $<18$ points were excluded. ${ }^{24}$

\section{Structured Clinical Interview for DSM Axis I Disorders (SCID-I)}

This instrument is widely used to assess axis I psychiatric disorders according to criteria from the Diagnostic and Statistical Manual of Mental Disorders, 4th edition (DSM-IV). The purpose was to identify crack dependence and other axis I psychiatric disorders.

\section{Profile of crack use ${ }^{25}$}

Detailed information about crack cocaine use was obtained using a questionnaire developed by the Center for Drug and Alcohol Research (CPAD) of Hospital de Clínicas de Porto Alegre, ${ }^{25}$ but not yet validated (entitled the Profile of the Crack User). This scale is comprised of 27 questions about the intensity, impact, and evolution of crack use.

\section{Ethics and research procedures}

This study was carried out in accordance with the recommendations of the Brazilian National Health Council and was approved by the ethics committee of Universidade Federal do Rio Grande do Sul (UFGRS; CAAE 12130813.3.0000.5334). The directors and managers of the therapeutic communities signed an agreement statement authorizing the study, and the participants also signed a consent form. All subjects included in the analysis provided written informed consent and no one refused to participate or complete the study protocol. Data were collected individually in adequate settings.

\section{Statistical analysis}

Descriptive analyses were performed using the Statistical Package for the Social Sciences (SPSS) version 23.0. Percentages, frequencies, means, standard deviation, medians, minimum, and maximum values were calculated.

\section{Results}

The 46 female crack users participating in this study had a mean age of 31.02 years (standard deviation $[S D]=7.73)$. The majority of women were single $(76.1 \%) ; 76.10 \%$ had at least one child. Among those with children, $34.8 \%$ reported having a child after beginning to use crack, and $19.6 \%$ reported at least one spontaneous abortion after starting using crack. Almost half of the sample had low education, with $43.5 \%$ having complete or incomplete elementary education. In addition, $80.4 \%$ of the participants were not working prior to the current treatment. Table 1 shows the distribution of women throughout the categories of sociodemographic variables.

At the moment of hospitalization, only $19.6 \%$ of the participants were employed. The majority of women $(69.6 \%)$ sought treatment spontaneously or through a spouse, family member, or friend referral. Only $10.9 \%$

Table 1 - Sociodemographic characteristics of female users of crack receiving treatment at therapeutic communities in the metropolitan area of Porto Alegre, southern Brazil

\begin{tabular}{lcc}
\hline Variable & $\mathbf{n}=\mathbf{4 6}$ & \% \\
\hline Ethnicity & 31 & 67.4 \\
White & 15 & 32.6 \\
Non-white & & \\
& & \\
Marital status & 35 & 76.1 \\
Single & 5 & 10.9 \\
Married/with partner & 2 & 4.3 \\
Separated & 4 & 8.7 \\
Divorced & & \\
& & \\
Education & 20 & 43.5 \\
Elementary school & 18 & 39.1 \\
High school & 8 & 17.4 \\
Higher education & & \\
& & \\
Monthly income (minimum wages) & & 21.7 \\
$\leq 1$ & 10 & 56.5 \\
1-3 & 26 & 13.0 \\
4-6 & 2 & 4.3 \\
7-10 & & \\
\hline
\end{tabular}

Trends Psychiatry Psychother. 2019;41(4) - 371 
mentioned having been referred to treatment by an institution or health professional. However, $27.5 \%$ had received previous in-patient treatment (mean $=3.37$, $\mathrm{SD}=5.49$ ). The participants were also asked to inform age upon first crack use, total number of years using crack, days of current treatment, days of abstinence, and number of previous treatments (Table 2).

Regarding crack consumption patterns, 65.2\% of the women reported using crack every day. Most participants $(46.3 \%)$ indicated smoking between 10 and 30 crack rocks per week, and $41.5 \%$ reported smoking more than 50 crack rocks per week. Also, $65.2 \%$ reported smoking more than 10 rocks in a single occasion, and the majority of women (76.4\%) reported the beginning of the nighttime as the period when they most commonly used crack. Finally, 65.2\% reported smoking crack from aluminum pipes.

Of all the 46 women interviewed, $34.8 \%$ drank alcohol at a frequency of 4 to 19 days a month, $80.4 \%$ smoked tobacco every day or almost every day ( $\geq 20$ days a month), and $71.7 \%$ used other illicit drugs every day or almost every day ( $\geq 20$ days a month). They also reported using crack simultaneously with other drugs (52.2\%). In relation to the use of other drugs, $100 \%$ reported having used crack along with tobacco, $97.8 \%$ with alcohol, $84.8 \%$ with marijuana, $47.0 \%$ with hashish and poppers, $34.8 \%$ with glue, $32.6 \%$ with loló and $17.4 \%$ with hallucinogenic tea.

Curiosity $(78.3 \%)$ was the most frequently reported reason for first-time crack use. Other reasons were: friends' influence $(63.0 \%)$, seeking relief from negative emotions $(65.2 \%)$, and confidence $(60.9 \%)$. Only $6.5 \%$ of the participants reported being users of intravenous drugs and changed to crack because they feared being infected with HIV or hepatitis.

The negative physical effects of crack use reported by the participants were weight loss $(93.5 \%)$, sleep problems $(87.0 \%)$, cough $(69.6 \%)$, shaking $(67.4 \%)$, energy loss (65.2\%), heart palpitations (65.2\%), and lip and hand burns (56.5\%). Regarding the consequences of crack use on social relationships, $82.6 \%$ reported an increase of arguments with family members and/ or partners, with $73.9 \%$ reporting separation from partners, and $60.9 \%$ being threatened with separation or being expelled from home. In addition, $67.4 \%$ reported having skipped days of work, and $58.7 \%$ indicated decreased work productivity.

Participants also reported a decrease in sexual desire $(89.1 \%)$, isolation from family and friends $(89.1 \%)$, and $87 \%$ indicated an increase in memory recollection deficits. Furthermore, $87.0 \%$ became more suspicious of other people, $78.3 \%$ reported losing interest in other people, and $56.5 \%$ became more aggressive. Concerning financial issues, $82.6 \%$ of the women reported having spent all their financial resources, and $71.7 \%$ started selling or trading their belongings to buy crack. A further $71.7 \%$ reported not being able to pay their bills, and $65.2 \%$ got involved in illicit activities to obtain money to buy the drug, including engaging in undesired sexual relationships (58.7\%) and getting involved with drug trafficking activities (54.3\%).

In regard to axis I psychiatric comorbidities, $70.0 \%$ presented at least one additional diagnosis. In fact, $56.5 \%$ had attempted suicide at least once, and $63.0 \%$ were using psychiatric medication during the current treatment. The frequencies and percentages of psychiatric disorders are displayed in Table 3.

Table 3 - Frequency and percentage of axis I psychiatric disorders

\begin{tabular}{lcc}
\hline Psychiatric comorbidities & $\mathbf{n ~ = ~ 4 6}$ & $\mathbf{\%}$ \\
\hline $\begin{array}{l}\text { Mood disorders } \\
\text { Major depressive episode }\end{array}$ & 28 & 60.87 \\
& & \\
Anxiety disorders & 24 & 52.17 \\
Post-traumatic stress disorder & 6 & 13.04 \\
Generalized anxiety disorder & 5 & 10.87 \\
Panic & 4 & 8.70 \\
Obsessive-compulsive disorder & \multicolumn{2}{c}{} \\
\hline
\end{tabular}

Table 2 - Crack consumption and related variables

\begin{tabular}{|c|c|c|c|}
\hline Variables & Minimum & Maximum & Mean (SD) \\
\hline Duration of treatment (days)* & 1 & 385 & $63.56(75.85)$ \\
\hline Period of abstinence (days) ${ }^{+}$ & 20 & 385 & $80.41(74.52)$ \\
\hline Number of previous treatments & 0 & 25 & $3.37(5.49)$ \\
\hline Age upon first use of crack & 12 & 45 & $22.61(8.06)$ \\
\hline Total time of crack use (months) & 2 & 360 & $82.26(74.76)$ \\
\hline
\end{tabular}

SD = standard deviation

* Treatment time considering only the therapeutic communities.

+ Number of days without crack use, including the detoxification time at the hospital, before treatment at the therapeutic communities. 


\section{Discussion}

The aim of the present study was to describe sociodemographic characteristics, consumption patterns, and psychiatric comorbidities in female crack users. The study showed that more than half of the women reported using crack on a daily basis (65.2\%). A similar percentage was found in a study with crack users undergoing in-patient treatment in hospitals and private clinics in the same city (Porto Alegre, state of Rio Grande do Sul, southern Brazil), ${ }^{26}$ where $53.6 \%$ of the patients reported using crack every day. However, it is important to highlight that their sample was mixed, with the majority being male $(90.5 \%)$.

The women in the present study had been abstaining from crack use between 20 and 385 days (mean = 80.41 days, SD $=74.52$ ). This variability in abstinence duration may be explained by the type of mental health service provided to crack users. Within the therapeutic community, one of the components of the psychosocial care plan provided by the Brazilian Unified Health System is that patients are offered long-term residential care. ${ }^{27}$ Typically, prior to receiving treatment at a therapeutic community, patients undergo an in-patient treatment at a hospital for detoxification, for a period of approximately 20 days. The main purpose of the therapeutic community is then to promote interaction among peers, so as to strengthen social reintegration and develop individual autonomy. ${ }^{28}$ Having success in a treatment strategy that includes prolonged stay at a therapeutic community may explain the variability in crack abstinence.

In this study, the most prevalent diagnoses were major depressive episode $(60.87 \%)$, followed by posttraumatic stress disorder (52.17\%) and generalized anxiety disorder (13.07\%). Psychiatric comorbidities, such as anxiety and depressive disorders, are commonly found in concurrency with drug dependency, 19,20,29 and studies have described associations between posttraumatic stress disorder and crack use.20,23 Thus, a connection between crack usage and psychiatric comorbidities is evident.

Regarding working activities, only $19.6 \%$ of the women were employed at the time of their hospitalization for the current treatment. This characteristic may be related to the fact that crack users commonly present impaired cognitive function and inadequate social behaviors, and therefore manifest difficulties related to being able to get a job and remain stable in a productive activity. Many women may have dropped out of their jobs because of drug-related problems.

As revealing as the current study is, several limitations should be addressed. First, the sample of crack users consisted of only 46 women. The data obtained from this sample should therefore be interpreted carefully, especially when trying to translate results to a broader clinical population. Conversely, it is important to highlight that clinical samples focusing on crack-related concerns are very specific and difficult to access. Second, the pattern of crack consumption in the current sample can be regarded as heterogeneous. Further investigation of the possible role of duration/frequency of crack use in identifying subgroups and treatment response is advisable. Third, and most importantly, polydrug use was found to be a common practice among crack users. In this sense, the selection of individuals that use solely crack is not only challenging, but also does not adequately reflect the population. Nonetheless, the interplay between crack and other drugs can be investigated in future studies.

In conclusion, it is important to emphasize the importance of these findings, especially because the majority of the studies available in the literature address male individuals or mixed samples, and commonly patients under treatment at hospital facilities. Overall, the few studies describing a female population involve crack users hospitalized for detoxification. Considering the peculiarities of the female sample in the present study, aspects are highlighted that could be helpful in developing strategies more focused on the patterns and the needs of this population.

Achieving a better understanding of the sociodemographic characteristics, patterns of crack use, and psychiatric comorbidities of women who use crack is a very important effort to develop future strategies for intervention and prevention programs tailored to this specific population. Our findings may contribute to the development of public health policies and treatments or rehabilitation programs that consider the specificities of these women.

\section{Acknowledgements}

This study was supported by a grant from Conselho Nacional de Desenvolvimento Científico e Tecnológico (CNPq), Ministério da Ciência, Tecnologia e Inovação (MCTI/CNPq/MEC/CAPES no 18/2012).

\section{Disclosure}

No conflicts of interest declared concerning the publication of this article. 


\section{References}

1. United Nations Office on Drugs and Crime. World Drug Report 2018. [cited 2018 Nov 07]. http://www.unodc.org/wdr2018/ index.html

2. Abdalla RR, Madruga CS, Ribeiro M, Pinsky I, Caetano R, Laranjeira R. Prevalence of cocaine use in Brazil: data from the II Brazilian National Alcohol and Drugs Survey (BNADS). Addict Behav. 2014;39:297-311.

3. Laranjeira R, Madruga CS, Pinsky I, Caetano R, Mitsuhiro SS. II Levantamento Nacional de Álcool e Drogas (LENAD). 2012. [cited 2018 Nov 07]. http://inpad.org.br/wp-content/uploads/2014/03/ Lenad-II-Relat\%C3\%B3rio.pdf

4. Volkow ND, Wise RA, Baler R. The dopamine motive system: implications for drug and food addiction. Nat Rev Neurosci. 2017;18:741-52.

5. Volkow ND, Morales $M$. The brain on drugs: from reward to addiction. Cell. 2015;162:712-25.

6. Ribeiro M, Dunn J, Sesso R, Lima MS, Laranjeira R. Crack cocaine: a five-year follow-up study of treated patients. Eur Addict Res. 2007;13:11-9.

7. Lozano OM, Domingo-Salvany A, Martinez-Alonso M, Brugal MT, Alonso J, de la Fuente L, et al. Health-related quality of life in young cocaine users and associated factors. Qual Life Res. 2008; 17:977-85.

8. Oliveira LG, Nappo SA. Caracterização da cultura de crack na cidade de São Paulo: padrão de uso controlado. Rev Saude Publica. 2008;42:664-71.

9. Duailibi LB, Ribeiro M, Laranjeira R. Profile of cocaine and crack users in Brazil. Cad Saude Publica. 2008;24:s545-57.

10. Santos Cruz M, Andrade T, Bastos FI, Leal E, Bertoni N, Villar LM, et al. Key drug use, health and socio-economic characteristics of young crack users in two Brazilian cities. Int J Drug Policy. $2013 ; 24: 432-8$

11. Bertoni N, Burnett C, Cruz MS, Andrade T, Bastos FI, Leal E, et al. Exploring sex differences in drug use, health and service use characteristics among young urban crack users in Brazil. Int J Equity Health. 2014;13:70-81.

12. Green CA. Gender and use of substance abuse treatment services. Alcohol Res Health. 2006;29:55-62.

13. Guimarães CF, Santos DVV, Freitas RC, Araujo RB. Perfil do usuário de crack e fatores relacionados à criminalidade em unidade de internação para desintoxicação no Hospital Psiquiátrico São Pedro de Porto Alegre (RS). Rev Psiquiatr Rio Gd Sul. 2008;30:101-8.

14. Moreira MM, Barbosa GL, Laranjeira R, Mitsuhiro SS. Alcohol and crack cocaine use in women: a 14-year cross-sectional study. J Addict Dis. 2014;33:9-14.

15. Hecksher D, Hesse M. Women and substance use disorders. Mens Sana Monogr. 2009; 7:50-62.

16. Copeland J. A qualitative study of barriers to formal treatment among women who self-managed change in addictive behaviours. J Subst Abuse Treat. 1997;14:183-90.
17. Paim Kessler FH, Barbosa Terra M, Faller S, Ravy Stolf A, Carolina Peuker A, Benzano D, et al. Crack users show high rates of antisocial personality disorder, engagement in illegal activities and other psychosocial problems. Am J Addict. 2012;21:370-80.

18. Narvaez JC, Jansen K, Pinheiro RT, Kapczinski F, Silva RA, Pechansky $F$, et al. Violent and sexual behaviors and lifetime use of crack cocaine: a population-based study in Brazil. Soc Psychiatry Psychiatr Epidemiol. 2014;49:1249-55.

19. Narvaez JC, Jansen $K$, Pinheiro RT, Kapczinski $F$, Silva RA Pechansky $F$, et al. Psychiatric and substance-use comorbidities associated with lifetime crack cocaine use in young adults in the general population. Compr Psychiatry. 2014;55:1369-76.

20. Hess ARB, Almeida RMM, Moraes AL. Psychiatric comorbidities in abstinent drug addict in a protected environment. Estud Psicol Natal. 2012;17:171-8.

21. Kokkevi A, Stefanis C. Drug abuse and psychiatric comorbidity. Compr Psychiatry. 1995;36:329-37.

22. Alves H, Kessler F, Ratto LRC. Comorbidity: alcohol use and other psychiatric disorders. Braz J Psychiatry. 2004;26:51-3.

23. Tull MT, Trotman A, Duplinsky MS, Reynolds EK, Daughters SB, Potenza MN, et al. The effect of posttraumatic stress disorder on risk-taking propensity among crack/cocaine users in residential substance abuse treatment. Depress Anxiety. 2009;26:1158-64.

24. Bertolucci PHF, Brucki SMD, Campacci SR, Juliano Y. O MiniExame do Estado Mental em uma população geral: impacto da escolaridade. Arq Neuro-Psiquiatr. 1994;52:01-7.

25. von Diemen L, Kapczinski F, Sordi AO, Narvaez JCM, Guimarães $\mathrm{LS}$, Kessler $\mathrm{FH}$, et al. Increase in brain-derived neurotrophic factor expression in early crack cocaine withdrawal. Int J Neuropsychopharmacol. 2014;17:33-40.

26. Sayago CBW, Lucena-Santos P, Horta RL, Oliveira MS. Perfil clínico e cognitivo de usuários de crack internados. Psicol Reflex Crit. 2014;27:21-8.

27. Brasil, Ministério da Saúde. Portaria No 131, de 26 de janeiro de 2012 [Internet]. [cited 2018 Nov 07]. http://bvsms.saude.gov. br/bvs/saudelegis/gm/2012/prt0131_26_01_2012.html

28. Strain EC. Assessment and treatment of comorbid psychiatric disorders in opioid-dependent patients. Clin J Pain. 2002;18:S1427

29. Scheffer M, Pasa GG, de Almeida RMM. Dependência de álcool, cocaína e crack e transtornos psiquiátricos. Psic Teor Pesq. 2010;26:533-41.

\section{Correspondence:}

Rosa Maria Martins de Almeida

Instituto de Psicologia, Universidade Federal do Rio Grande do Sul

Rua Ramiro Barcelos, 2600, Bairro Santa Cecília

90035-003 - Porto Alegre, RS - Brazil

Tel.: +55 (51) 33085066, Fax: +55 (51) 33085470

E-mail: rosa.almeida@ufrgs.br 